\title{
Pengembangan Kultur Sekolah Berbasis Syariah dalam Pembentukan Karakter Siswa di SMK IT Smart Informatika Surakarta
}

\author{
Nur Hidayah \\ SDN Pajang IV Laweyan Surakarta \\ e-mail: nurhidayah338@gmail.com
}

\begin{abstract}
Objective of this study is to determine development of sharia-based school culture in creating character education of students in The Integrated Islamic Vocational School (SMK IT) of Surakarta which includes factors inhibiting development of school culture and the Sharia-based solution. This study is a qualitative descriptive one. The research was conducted at SMK IT. Subjects of this study is principal, student andvice principal of student affairsof the school, while teacher, homeroom, teacher of guidance and counseling, boardinghouse caregiver as an informant. Methods of data collection used interview, observation and documentation. The results showed that the shariabased school culture that has been developed through religious activities and school culture coming from moral values of Islam can lead to character education in everyday life, in practice there were some obstacles derived from both internal and external of the school. Internal barriers were innate character of students, lack of infrastructure, unstable team work, educational background of the student, and wicked nature of the student. As for the external factors were obstacles derived from negative impact of globalization and technological sophistication, lack of support from parents, social influence, influence of social patterns before staying at the boardinghouse.
\end{abstract}

Keywords: School Culture, Sharia Culture Development, Character Education 


\section{Pendahuluan}

Dalam rangka meningkatkan mutu pendidikan, pemerintah telah menempuh berbagai jalan guna mendongkrak kualitas pendidikan nasional. Mulai dari pemberdayaan Lembaga Peningkatan Mutu Pendidikan (LPMP), peningkatan profesionalisme guru melalui diklat, penataran guru dan program sertifikasi, pemberian Bantuan Operasional Sekolah (BOS), pengadaan sarana prasarana dan lain sebagainya.

Namun hasil yang nampak, kualitas pendidikan nasional masih rendah. Hal ini tercermin pada data indeks pembangunan manusia (IPM). Dengan menggunakan Indeks Pembangunan Manusia Indonesia (IPM) yaitu kombinasi dari indikator- indikator seperti kesehatan, kekayaan dan pendidikan, peringkat Indonesia di tahun 2014 berada pada posisi 108 dari 187 negara. Dengan pengecualian dari Singapora (9), Brunei (30), Malaysia (62), dan Thailand (89), negara-negara anggota ASEAN lainya menempati peringkat lebih rendah dari Myanmar (150), Laos (139), Kamboja (136), Vietnam (121) dan Filipina (117) (BPS, 2015).

Rendahnya IPM berimplikasi pada rendahnya mutu interaksi sosial di tengah masyarakat. Dalam kehidupan para pelajar dan mahasiswa, data-data penelitian menunjukkan angka yang mengkhawatirkan. Menurut survey Komisi Perlindungan Anak (KPA) yang dilakukan terhadap 4.500 remaja di 12 kota besar seluruh Indonesia ditemukan hasil bahwa 62,7 \% remaja mengaku pernah berhubungan badan, $93 \%$ remaja pernah berciuman dan 21\% remaja pernah melakukan aborsi (Kompas.com, 9/5/2010).

Belum lagi di kalangan birokrat dan pejabat, yang notabene kaum cerdik pandai. Terjadi krisis mental dan kepribadian yang cukup parah. Banyaknya pejabat yang korupsi, akademisi yang banyak dibui merupakan sinyalemen menurunnya kualitas kepribadian dunia pendidikan. Kenyataan di atas menggambarkan bahwa pendidikan belum dapat mewarnai kehidupan masyarakat khususnya kehidupan pelajar. Diperlukan usaha yang komprehensif dalam meningkatkan kualitas pendidikan Islam di Indonesia. Selain melalui pendekatan konvensional juga diperlukan peningkatan kualitas pendidikan melalui pendekatan inkonvensional.

Kurangnya pendekatan kultur oleh institusi pendidikan dianggap menjadi penyebab kurang optimalnya hasil dari upaya peningkatan kualitas pendidikan. 
Pendekatan mutu yang ditempuh saat ini banyak bertumpu pada sisi konvensional. Institusi pendidikan hanya terfokus pada peningkatan kualitas proses belajar mengajar, peningkatan kualitas guru mengajar, penambahan sarana prasana pendidikan dan lain sebagainya. Kurang menyentuh sisi inkonvensional misalnya kultur sekolah. Padahal, sekolah sebagai sebuah sistem terdiri atas proses belajar mengajar, kepemimpinan, manajemen dan kultur sekolah. Di sinilah diperlukan pendekatan yang komprehensif antara pendekatan konvensional dan inkonvensional.

SMK IT Smart Informatika (Sekolah Menengah Kejuruan Islam Terpadu Smart Informatika) Surakarta sebagai sekolah Islam Terpadu membangun sekolahnya di atas landasan dan manajemen syariah. Jaminan mutu yang diberikan adalah: Pembiasaan ibadah sehari-hari seperti membaca Al Qur'an, sholat berjama'ah, dzikir dan lain-lain. Lingkungan sekolah Islami seperti pemisahan putra dan putri baik kelas maupun dalam berbagai kegiatan. Siswa lulus dari SMK IT Smart Informatika Surakarta memiliki hafalan Al Qur'an minimal 5 Juz dan mampu membaca Al Qur'an dengan tartil. Tidak ada Ustadz (Guru Putra) maupun karyawan yang merokok di sekolah maupun di rumah, Semua Ustadzah (Guru Putri) maupun karyawati berbusana muslimah baik di sekolah maupun di rumah.

Bangunan karakter yang ingin diwujudkan adalah menjadikan Islam sebagai landasan filosofis, mengintegrasikan nilai Islam ke dalam bangunan kurikulum, menerapkan dan mengembangkan metode pembelajaran untuk mencapai optimalisasi proses belajar mengajar. Mengedepankan qudwah hasanah dalam membentuk karakter peserta didik. Menumbuhkan iklim dan lingkungan sekolah yang syar'i, menumbuhkan kemaslahatan dan meniadakan kemaksiatan dan kemungkaran.

Dari uraian latar belakang permasalahan tersebut dapat dirumuskan permasalahan antara lain: Bagaimanakah pengembangan kultur sekolah berbasis syariah pada pendidikan karakter di SMK IT Smart Informatika Surakarta, Apa hambatan pengembangan kultur sekolah berbasis syariah dalam pembentukan karakter siswa di SMK IT Smart Informatika Surakarta, serta Apa solusi pengembangan kultur sekolah berbasis syariah dalam pembentukan karakter siswa di SMK IT Smart Informatika Surakarta?

| Volume. 1, No. 1, Januari-Juni 2016 


\section{Kultur Sekolah dan Basis Syariah}

Koentjaraningrat (1974:83) menyebutkan unsur-unsur universal dari kebudayaan adalah meliputi: (1) sistem religi dan upacara keagamaan, (2) sistem dan organisasi kemasyarakatan, (3) sistem pengetahuan, (4) bahasa, (5) kesenian, (6) sistem mata pencaharian hidup, dan (7) sistem teknologi dan peralatan. Selanjutnya dijelaskan bahwa budaya itu paling sedikit mempunyai tiga wujud, yaitu kebudayaan sebagai: (1) suatu kompleks ide-ide, gagasan, nilai-nilai, norma-norma; (2) suatu kompleks aktivitas kelakukan dari manusia dalam masyarakat; dan (3) sebagai benda-benda karya manusia.

Tiga macam wujud budaya di atas, dalam konteks organisasi disebut dengan budaya organisasi (organizational culture). Dalam konteks perusahaan, diistilahkan dengan budaya perusahaan (corporate culture), dan pada lembaga pendidikan/sekolah disebut dengan budaya sekolah (school culture).

Basis Syariah, Menurut Widjajakusuma M.K dan Yusanto M.I (2003), syariah memandang manajemen dari dua sisi, yaitu manajemen sebagai ilmu dan manajemen sebagai aktivitas. Sebagai ilmu, manajemen dipandang sebagai salah satu dari ilmu umum yang lahir berdasarkan fakta empiris yang tidak berkaitan dengan nilai, peradaban (hadharah) manapun. Namun sebagai aktivitas, maka manajemen dipandang sebagai sebuah amal yang akan dimintai pertanggungjawaban di hadapan Allah SWT, sehingga ia harus terikat pada aturan syara', nilai dan hadharah Islam. Manajemen Islami (syariah) berpijak pada aqidah Islam. Karena aqidah Islam merupakan dasar ilmu pengetahuan atau tsaqofah Islam.

Dalam ranah aktivitas, Islam memandang bahwa keberadaan manajemen sebagai suatu kebutuhan yang tak terelakkan dalam memudahkan implementasi Islam dalam kehidupan pribadi, keluarga dan masyarakat. Implementasi nilai- nilai Islam berwujud pada difungsikannya Islam sebagai kaidah berpikir dan kaidah amal dalam kehidupan. Sebagai kaidah berpikir, aqidah dan syariah difungsikan sebagai asas dan landasan pola pikir. Sedangkan sebagai kaidah amal, syariah difungsikan sebagai tolok ukur (standar) perbuatan. Manajemen bisa dikatakan telah memenuhi syariah bila: pertama, manajemen ini mementingkan perilaku yang terkait denga nilai-nilai keimanan dan ketauhidan. Kedua, manajemen syariah pun mementingkan adanya struktur organisasi. 


\section{Manajemen Syariah, Budaya Organisasi, dan Konsep Pendidikan Karakter}

Budaya organisasi adalah sekumpulan asumsi penting (keyakinan dan nilai) yang mempengaruhi opini dan tindakan dalam suatu perusahaan (Pearce dan Robinson dalam Yusanto, MI dan Widjayakusuma MK, 2003). Dalam konteks sekolah, budaya organisasi berarti sekumpulan asumsi penting yang berupa keyakinan, aktifitas dan artefak organisasi yang mempengaruhi opini dan tindakan warga sekolah. Manajemen dan budaya organisasi memiliki hubungan yang erat, manajemen membutuhkan budaya organisasi untuk mendinamiskan kinerja sementara budaya organisasi membutuhkan manajemen untuk mewujudkan dan mengaktualisasikan budaya yang dikonsepnya. Menurut Albrecht dalam Yusanto dan Wijdayakusuma (2003), budaya organisasi perlu dirumuskan dan diwujudkan melalui visi, misi dan tujuan organisasi. Disinilah pentingnya fungsi perencanaan dalam manajemen. Sementara dalam tataran proses perlu peran strategis pemimpin organisasi dan peran aktif seluruh anggota organisasi. Lebih lanjut dalam aplikasinya budaya akan menjadi budaya organisasi apabila telah menjadi denyut nadi di seluruh kehidupan organisasi. Dalam tahapan berikutnya budaya organisasi perlu dikontrol pelaksanaannya, perlu dievaluasi bahkan dalam keadaan tertentu perlu dirumuskan kembali apabila tidak sejalan dengan maksud organisasi. Dalam tataran inilah diperlukan fungsi pengontrolan dan evaluasi.

Pengertian karakter menurut Pusat Bahasa Depdiknas adalah "bawaan, hati, jiwa, kepribadian, budi pekerti, perilaku, personalitas, sifat, tabiat, temperamen, watak". Adapun karakter adalah berkepribadian, berperilaku, bersifat, bertabiat, dan berwatak". Menurut Aristoteles dalam Manshur (2011: 32) karakter erat kaitannya dengan habit atau kebiasaan yang terus menerus dilakukan, mengacu kepada serangkaian sikap (attitudes), perilaku (behavior), motivasi (motivations), dan ketrampilan (skill). Karakter berasal dari bahasa Yunani yang berarti "to mark" atau menandai dan memfokuskan bagaimana mengaplikasikan nilai kebaikan dalam bentuk tindakan atau tingkah laku, sehingga orang yang tidak jujur, kejam dan perilaku jelek lainnya dikatakan orang berkarakter jelek. Sebaliknya, orang yang perilakunya sesuai dengan kaidah moral disebut dengan berkarakter mulia.

Karakter mulia berarti individu memiliki pengetahuan tentang potensi dirinya, yang ditandai dengan nilai-nilai seperti reflektif, percaya diri, rasional, logis, kritis,

| Volume. 1, No. 1, Januari-Juni 2016 
analitis, kreatif dan inovatif, mandiri, hidup sehat, bertanggung jawab, cinta ilmu, sabar, berhati-hati, rela berkorban, pemberani, dapat dipercaya, jujur, menepati janji, adil, rendah hati, malu berbuat salah, pemaaf, berhati lembut, setia, bekerja keras, tekun, ulet/gigih, teliti, berinisiatif, berfikir positif, disiplin, antisipatif, inisiatif, visioner, bersahaja, bersemangat, dinamis, hemat/efisien, menghargai waktu, pengabdian/ dedikatif, pengendalian diri, produktif, ramah, cinta keindahan (estetis), sportif, tabah, terbuka, tertib.

Pendidikan karakter adalah suatu sistem penanaman nilai-nilai karakter kepada warga sekolah yang meliputi komponen pengetahuan, kesadaran atau kemauan, dan tindakan untuk melaksanakan nilai-nilai tersebut. Pendidikan karakter dapat dimaknai sebagai nilai dasar yang membangun pribadi seseorang, terbentuk baik karena pengaruh hereditas maupun pengaruh lingkungan, yang membedakannya dengan orang lain, serta diwujudkan dalam sikap dan perilakunya dalam kehidupan sehari-hari. (Muchlas dan Hariyanto, 2012: 43). Dalam pendidikan karakter di sekolah, semua kompnen (pemangku pendidikan) harus dilibatkan, termasuk komponen-komponen pendidikan itu sendiri, yaitu isi kurikulum, proses pembelajaran dan penilaian, penanganan atau pengelolaan sekolah, pelaksanaan aktivitas tau kegiatan ko-kurikuler, serta pemberdayaan sarana prasarana, pembiayaan, dan etos kerja selluruh warga sekolah/lingkungan. Di samping itu, pendidikan karakter dimaknai sebagai suatu perilaku warga sekolah yang dalam menyelenggarakan pendidikan harus berkarakter.

Pendidikan karakter merupakan upaya-upaya yang dirancang dan dilaksanakan secara sistematis untuk membantu peserta didik memahami nilai-nilai perilaku manusia yang berhubungan dengan Tuhan Yang Maha Esa, diri sendiri, sesama manusia, lingkungan, dan kebangsaan yang terwujud dalam Saran, sikap, perasaan, perlcataan, dan perbuatan berdasarkan norma-norma agama, hukum, tata krama, budaya, dan adat istiadat. Nilai-nilai pendidikan sendiri adalah suatu makna dan ukuran yang tepat dan akurat yang mempengaruhi adanya pendidikan itu sendiri. Di antara Nilai-nilai dalam Pendidikan Karakter Bangsa ada 18 unsur dan nilai yang mana diantaranya adalah:(1) Religius, (2) Jujur, (3) Toleransi, (4) Disiplin, (5) Kerja Keras, (6) Kreatif, (7) Mandiri, (8) Demokratis, (9) Rasa Ingin Tahu, (10) Semangat Kebangsaan, (11) Cinta Tanah Air, 
(12) Menghargai Prestasi, (11) Bersahabat/Komunikatif, (14) Cinta Damai, (15) Gemar Membaca, (16) Peduli Lingkungan, (17) Peduli Sosial, (18) Tanggung-jawab.

Kurikulum di SMK IT Smart Informatika Surakarta mengimplementasikan delapan belas butir nilai pendidikan karakter yang telah dirumuskan oleh Kementrian Pendidikan Nasional. Sesuai dengan rumusan tersebut, SMK IT Smart Informatika telah menerapkan beberapa nilai pendidikan karakter kepada siswa melalui proses pembelajaran di kelas dan pembiasaan di lingkungan sekolah.

\section{Metode Penelitian}

Penelitian ini merupakan penelitian deskriptif kualitatif. Yaitu suatu penelitian yang bertujuan untuk menerangkan fenomena-fenomena sosial/suatu peristiwa. Penelitian ini mengambil tempat di SMK IT Smart Informatika Surakarta yang beralamat di Jl. Srigunting VII Rt 04 Rw XI, Gremet, Manahan, Banjarsari, Surakarta, Jawa Tengah.

Dalam penelitian ini yang menjadi subyek penelitian adalah Kepala sekolah, Wakil kepala kesiswaan, dan siswa. Sedangkan informan dalam penelitian ini adalah 1) Guru PAI, 2) Wali kelas, 3) Gru BK, 4) Pengasuh asrama. Teknik pengumpulan data yang digunakan dalam penelitian ini adalah observasi, wawancara, dan dokumentasi.

Untuk pemeriksaan keabsahan, penulis menggunakan metode triangulasi. Triangulasi dalam penelitian ini diartikan sebagai pengujian keabsahan data yang diperoleh dari berbagai sumber, berbagai metode, dan berbagai waktu. Oleh karenanya peneliti malakukan teknik pengujian keabsahan data melalui triangulasi sumber, dan triangulasi metode.

Terkait dengan triangulasi sumber maka peneliti mengecek data yang telah diperoleh kepada beberapa sumber. Data yang diperoleh dideskripsikan, dikategorikan, manakah pandangan yang sama dan manakah yang berbeda serta manakah yang spesifik dari ketiga sumber tersebut. Data yang telah dianalisis sampai menghasilkan suatu kesimpulan selanjutnya dikonfirmasikan kepada ketiga narasumber. Data-data yang telah diperoleh dari hasil wawancara dapat disesuaikan dengan data observasi atau

| Volume. 1, No. 1, Januari-Juni 2016 
membandingkan data dari kepala sekolah, wakil kepala sekolah, wali kelas, guru, siswa, dan karyawan.

Sementara itu terkait dengan triangulasi teknik maka peneliti mengecek pada sumber yang sama tetapi dengan teknik berbeda. Misalnya data yang diperoleh melalui wawancara kemudian dicek dengan data hasil observasi, atau hasil analisis dokumen. Bila menghasilkan data berbeda, peneliti melakukan diskusi lebih lanjut dengan sumber data yang bersangkutan untuk mendapatkan data yang dianggap benar.

Data yang telah dilkakuan pemeriksaan keabsahannya dianalisis menggunakan reduksi data, penyajian data dan penarikan kesimpulan. Untuk itu, perlu melakukan analisis data peneliti mengacu kepada tahapan yang dijelaskan Miles dan Huberman (dalam Sugiyono, 2008: 246) yang terdiri dari tiga tahapan:

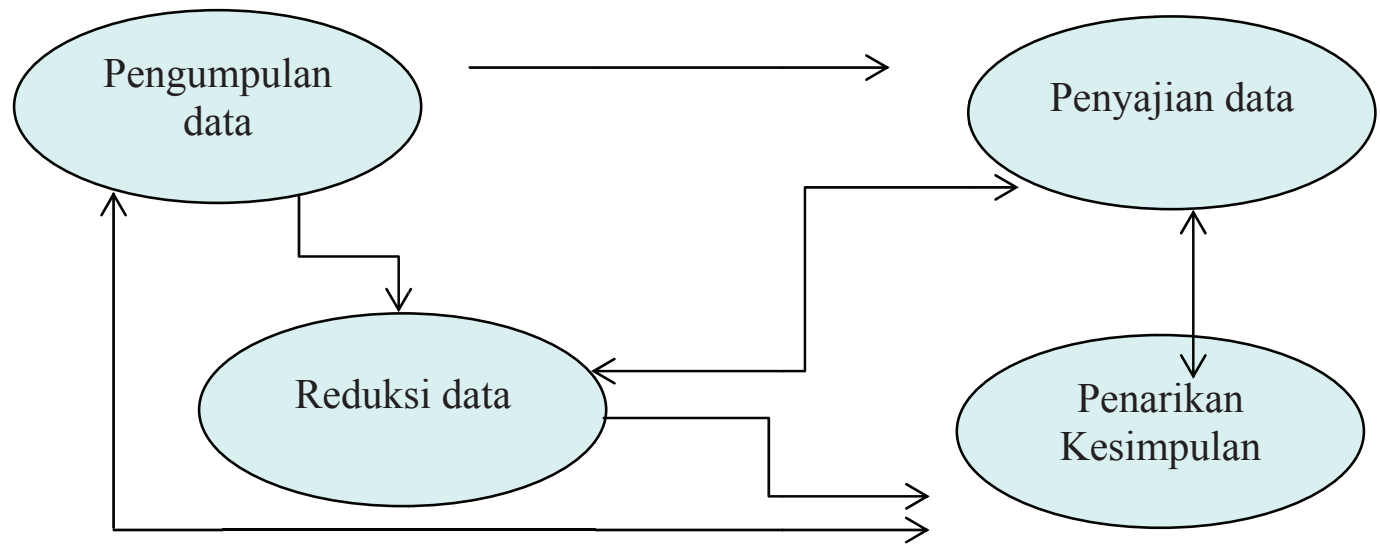

Komponen-komponen analisis data

(Model interaktif Miles dan Huberman, 1994: 12)

\section{Pembahasan}

\section{Manajemen Syariah dalam Pengembangan Kultur Sekolah}

Manajemen bisa dikatakan telah memenuhi syariah bila: pertama, manajemen ini mementingkan perilaku yang terkait denga nilai-nilai keimanan dan ketauhidan. Kedua, manajemen syariah pun mementingkan adanya struktur organisasi. Ketiga, manajemen syariah membahas soal sistem. Implementasi syariah dalam fungsi perencanaan adalah: a) Perencanaan bidang SDM. Implementasi syariah pada bidang ini berupa penetapan profesionalisme yang harus dimiliki oleh seluruh komponen SDM 
perusahaan. Kriteria profesional menurut syariah adalah harus memenuhi 3 unsur, yaitu kafa'ah (ahli di bidangnya), amanah (bersungguh-sungguh dan bertanggung jawab), memiliki etos kerja yang tinggi (himmatul 'amal). Kualifikasi umum yang harus dipenuhi SDM SMK IT Smart informatika Surakarta:muslim/muslimah (berpakaian syar'i), jujur, amanah, cekatan, disiplin, ramah, dan tidak merokok, aktif di masjid dan organisasi islam), selain kualifikasi umum tersebut di atas juga terdapat kualifikasi khusus sesuai dengan formasi yang dibutuhkan, misalnya sebagai berikut:Guru Tahfidz Kualifikasi:Pria/Wanita, Usia Maks. 30 Tahun, Memiliki hafalan Qur'an min. 5 Juz, Lulusan dari pondok pesantren/lembaga bahasa Arab, Mampu berbahasa Arab (lisan dan tulisan).

b) Perencanaan Bidang Keuangan. Permasalahan utama bidang keuangan adalah penetapan sumber dana dan alokasi pengeluaran. Implementasi syariah pada bidang ini berupa penetapan syarat kehalalan dana, baik sumber masukan maupun alokasinya. Maka, tidak pernah direncanakan, misalnya, peminjaman dana yang mengandung unsur riba, atau pemanfaatan dana untuk menyogok pejabat. Sumber dana di SMK IT Smart informatika Surakarta adalah dari Yayasan Solo Peduli dan pemerintah. Dana yang bersumber dari Yayasan Solo Peduli pada tahun pelajaran 2015/2016 ini tiap anak mendapat dana sebesar $\mathrm{Rp} 330.000$ pada tiap bulannya.Sedangkan dari pemerintah sama sebagimana sekolah yang lainnya yaitu bersumber dari BOS (Bantuan Operasional Sekolah). Besaran dananya tiap anak mendapat dana sebesar Rp. 1.200 .000 pertahun atau Rp 100.000 pada tiap bulannya. Berbicara mengenai dana, hal yang sama pentingnya dalam kacamata syariah selain membahas sumbernya adalah juga membahas peruntukan atau penggunaan dana yang telah di dapat. Penggunaan dana di SMK IT Smart informatika Surakarta didasarkan pada RKAS (Rencana Kegiatan Dan Anggaran Sekolah). Setelah penggunaan dana atau anggaran yang juga sangat penting adalah melakukan LPJ (Laporan Pertanggung Jawaban).

c) Perencanaan Bidang Operasi. Implementasi syariah dalam dunia pendidikan, yaitu di SMK IT Smart informatika Surakarta yaitu input SDM Muslim dan proses pendidikannya ditetapkan dengan menggunakan kurikulum KTSP dan Islami. Sementara proses pendidikan ditetapkan berlangsung secara aman dan tidak 
bertentangan dengan syariah. d) Perencanaan bidang pemasaran. Implementasi syariah pada bidang ini berupa segmen yang dibidik adalah SDM muslim. Target yang ingin dicapai adalah output didik (SDM) yang profesional. Target out put sebagai berikut: Hafal 5 juz Al Qur'an (Juz 1,2,3, 29,dan 30), hafal hadits arbain nawawi, memiliki kepribadian islam yang utuh, mampu berdakwah menjadi imam dan khotib, memiliki kemampampuan berorganisasi dan leadership, mampu berkomunikasi aktif dengan bahasa inggris dan bahasa arab, mampu menjadi tenaga ahli kelas menengah berstandar nasional dan internasional, memiliki jiwa kemandirian (enterprenuership), semua alumni (100\%) terserap ke dunia kerja dengan membuka lapangan kerja maupun menjadi karyawan. Sedangkan posisi yang ditetapkan adalah lembaga yang memiliki unique position sebagai lembaga pendidikan manajemen syariah.

\section{Peran Syariah dalam Pengorganisasian}

Dalam hal ini, meliputi aspek: a) Aspek Struktur. Implementasi pada SDM yaitu hal-hal yang berkorelasi dengan faktor Profesionalisme serta Aqad pekerjaan. Harus dihindarkan penempatan SDM pada struktur yan tidak sesuai dengan kafa'ahnya atau dengan aqad pekerjaannya. Yang pertama akan menyebabkan timbulnya kerusakan, dan yang kedua bertentangan dengan keharusan kesesuaian antara aqad dan pekerjaan. b) Aspek Tugas dan Wewenang. Implementasi syariah dalam hal ini terutama di tekankan pada kejelasan tugas dan wewenang masing-masing bidang yang diterima oleh para SDM pelaksana berdasarkan kesanggupan dan kemampuan masingmasing sesuai dengan aqad pekerjaan tersebut. c) Aspek Hubungan. Implementasi syariah pada aspek ini berupa penetapan budaya organisasi bahwa setiap interaksi antar SDM adalah hubungan muamalah yang selalu mengacu pada amar ma'ruf dan nahi munkar.

Implementasi syariah dalam fungsi pengarahan adalah merupakan tugas utama dari fungsi kepemimpinan. Fungsi kepemimpinan selain sebagai penggembala (pembimbing, pengarah, pemberi solusi dan fasilitator), maka implementasi syariah dalam fungsi pengarahan dapat dilaksankan pada dua fungsi utama dari kepemimpinan itu sendiri, yakni fungsi pemecahan masalah (pemberi solusi) dan fungsi sosial (fasilitator). 


\section{Peran Syariah dalam Pengawasan}

Pengawasan membutuhkan prasyarat adanya perencanaan yang jelas dan matang serta struktur organisasi yang tepat. Dalam konteks ini, implementasi syariah diwujudkan melalui tiga pilar pengawasan yaitu: a) Ketaqwaan individu,seluruh personel SDM perusahaan dipastikan dan dibina agar menjadi SDM yang bertaqwa. b) Kontrol anggota, proses keberlangsungan organisasi selalu akan mendapatkan pengawalan dari para SDM-nya agar sesuai dengan arah yang telah ditetapkan. c) Penerapan (supremasi) aturan,organisasi ditegakkan dengan aturan main yang jelas dan transparan serta-tentu saja-tidak bertentangan dengan syariah.

Pengembangan Kultur Sekolah Berbasis Syariah Berbasis Syariah dalam menimbulkan Pendidikan Karakter Siswa di SMK IT Smart Informatika Surakarta. Pendidikan Agama Islam (PAI) memiliki nilai yang lebih dalam penanaman nilai-nilai dan karakter terhadap anak didik. Pendidikan Agama Islam adalah ujung tombak dari pembangunan karakter anak didik. Hal ini berkaitan dengan karakteristik Pendidikan Agama Islam yang mengedepankan pencapaian afektif atau sikap yang terlihat dari perilaku anak didik. Pencapaian afektif atau lebih dikenal dengan istilah pencapaian nilai-nilai alchlak mulia menjadi hal yang menjadi perhatian Pendidikan Agam Islam. Pencapaian tersebut, bisa dilakukan manakala pencapaian pada level kognitif dan psikomotor lebih dahulu dilakukan. (mastery learning, ketuntatasan belajar). Penanaman nilai yang dimaksud dapat dilakukan dengan berbagai cam, antara lain: melalui pembiasaan, kegiatan elcstralcurikuler, tugas terstrulctur, tugas mandiri dan lain sebagainya. Semua itu bisa tercapai, jika ada kesamaan visi antara gum PAI sehagai pelaksana dan penanggungjawab program penanaman nilai dengan pihak sekolah sebagai pengelola.

Implementasi nilai-nilai pendidikan karakter dalam kehidupan sehari-hari seorang pelajar muslim harus mendasarkan diri pada ajaran agama (AI-Qur'an dan Sunnah). Hal ini diperlukan pengamatan yang komprehensif di lingkungan sekolah khususnya dan dikembangkan diluar sekolah atau di lingkungan masing-masing di bawah peligawasan orang tea. Pengamatan terhadap siswa dapat dilihat dan indikator sekolah, indikator kelas maupun indikator asrama dalam implementasinya terhadap nilai-nilai pendidikan karakter dalam penelitian ini yaitu karakter jujur, disiplin,

| Volume. 1, No. 1, Januari-Juni 2016 
tanggung jawab, dan peduli lingkungan.

Pengembangan kultur sekolah berbasis syariah di SMK IT Smart Informatika Surakarta tentunya tidak jauh berbeda dengan program lainnya. Hambatan-hambatan itu ada yang berasal dari faktor internal maupun ekstemal sekolah. Faktor internal antara lain minimnya saran dan prasarana dan tidak stabilnya team work. Adapun faktor ekstemalnya yaitu dampak negatif dari arus globalisasi dan kecanggihan teknologi, minimnya dukungan orang tua, dan pengaruh lingkungan di masyarakat.

Beberapa hambatan yang ada bukanlah menjadi penghalang bagi kami, akan tetapi justru kami merasa terpanggil untuk menyelesaikannya dan menjadikan sebuah motivasi yang tinggi untuk mengembangkannya. Karena kami yakin bahwa dibalik hambatan-hambatan tersebut masih banyak peluang yang memungkinkan terwujudnya kultur sekolah berbasis syariah di dalam lingkungan sekolah. Kata orang bijak: Jika kita melihat kekurangan itu sebagai kendala maka akan menghambat jalan kita, tetapi jika kita berfokus pada cara mengatasinya (peluang) maka hambatan itu akan hilang dengan sendirinya. Dan peluang-peluang itulah yang dijadikan pijakan sebagai solusi terhadap hambatan pengembangan kultur sekolah berbasis syariah di SMK IT Smart Informatika Surakarta.

Peluang-peluang tersebut ada yang berasal dari dalam lingkungan sekolah (faktor internal) dan ada yang dari luar lingkungan sekolah (faktor ekstemal). Peluang internalnya antara lain adanya niat dan mindset sama dalam keinginan mewujudkan dari team work, adanya dukungan kepala sekolah, seratus persen warga sekolah beragama Islam, dan adanya komitmen dari guru PA1. Sedangkan peluang ekstemalnya antara lain kebijakan pemerintah, kultur daerah, dan dukungan dan masyarakat sekitar dan keluarga.

\section{Kesimpulan}

Setelah melakukan kajian dalam penelitian ini maka dapat ditemukan hasil penelitian sebagai berikut: a) Kultur sekolah berbasis syariah dalam pendidikan karakter siswa di SMK IT Smart Informatika Surakarta melalui kegiatan-kegiatan keagamaan baik yang sifatnya rutinitas maupun insidental, dapat menimbulkan pendidikan karakter 
siswa yang melandasi perilaku, tradisi, kebiasaan sehari-hari, dan simbol-simbol yang dipraktikkan oleh siswa itu sendiri.

b) Hambatan pengembangan kultur sekolah berbasis syariah dalam pendidikan karakter siswa di SMK IT Smart Informatika Surakarta ada dua factor yaitu faktor internal dan faktor eksternal. Hambatan faktor internal yang dihadapi antara lain: karakter bawaan siswa, minimnya sarana prasarana, team work yang tidak stabil, latar belakang pendidikan siswa, dan sifat fasik siswa. Adapun hambatan faktor eksternalnya yaitu dampak negatif arus globalisasi dan kecanggihan teknologi, minimnya dukungan dari orang tua, pengaruh pergaulan, pengaruh pola pergaulan sebelum tinggal di asrama.

c) Adapun solusi dari hambatan tersebut berpijak pada peluang yang dapat dimanfaatkan untuk pengembangan kultur sekolah berbasis syariah dalam pendidikan karakter siswa di SMK IT Smart Informatika Surakarta sehingga dapat menimbulkan karakter siswa diantaranya karakter jujur, disiplin, tanggung jawab, dan peguli llingkungan. Peluang tersebut ada yang berasal dari dalam lingkungan sekolah (internal) da nada yang dari luar lingkungan sekolah (eksternal). Peluang internalnya antara lain adanya program edukasi, berupa pembinaan, support, pemberian reward and punishment, pendekatan personal, dan adanya komitmen dari stake holder pendidikan. Sedangkan faktor eksternal yang dapat dijadikan solusi adalah kebijakan pemerintah yang mendukung, kultur daerah yang Islami, dukungan keluarga dan masyarakat.

Berdasarkan hasil pembahasan penelitian dan kesimpulan di atas, maka dapat diberikan saran-saran sebagai berikut: a) Pengelola Yayasan Solo Peduli harus mensosialisasikan arah pembentukan nilai dan kultur sekolah seperti etos spiritual dan sikap mental positif melalui pembinaan-pembinaan serta menyelenggarakan pelatihan pelatihan manajemen syariah bagi guru dan karyawan.

b) Kepala sekolah hendaknya senantiasa menjaga nilai nilai budaya yang telah terinternalisasi pada diri siswa dan warga sekolah dengan kegiatan pembiasaan, membakukan implementasi syariah pada pola manajemen sekolah sehingga muncul brand image sekolah berbasis syariah, serta mempertahankan kultur Islami yang telah berkembang dan berusaha mengembangkan nilai-nilai Islami sebagai ruh bagi kegiatan pendidikan di sekolah.

| Volume. 1, No. 1, Januari-Juni 2016 
c) Guru dan Karyawan hendaknya senantiasa berpijak pada visi pembentukan kultur sekolah dan berusaha menggali inovasi pembiasaan yang lebih efektif dan efisien guna pencapaian target pembentukan kepribadian siswa. Atau minimal Istiqomah dengan program yang sudah ada. d) Siswa diharapkan mampu menjadikan kesadaran dan keikhlasan sebagai dasar dalam beramal dan beraktifitas, sehingga terbentuk nilai nilai kepribadian yang mulia. Disamping itu juga menjaga komitmen dan integritas sebagai siswa SMK IT Smart Informatika Surakarta dengan baik. 


\section{Daftar Pustaka}

Abdul Majid \& Dian Andayani. 2011. Pendidikan Karakter Perspektif Islam. Bandung: PT. Remaja Rosda Karya.

Ahmad Tafsir. 2008. Ilmu Pendidikan Dalam Perspektif Islam. Bandung: Rosda Karya.

Akhmad Sudrajat. 2011. 10 Aspek Degradasi Moral dan 11 Prinsip Pendidikan Karakter. https://akhmadsudrajat.wordpress.com/2011/07/31/degradasi-moraldan-prinsip-pendidikan-karakter/, diakses tanggal 22 Januari 2016

Andi Prastowo. 2011. Metode Penelitian Kualitatif dalam Perspektif Rancangan Penelitian. Jogjakarta: Ar-Ruzz Media.

Andre Ata Ujan dkk. 2009. Multikulturalisme, Belajar Hidup Bersama dalam Perbedaan. Jakarta Barat: PT. Indeks.

Anonim, 2011. Seks Bebas Kalangan Pelajar, Diakses dari http//: www.wartanews.com, diakses tanggal 23 Februari 2012

Ary Ginanjar Agustian. 2003. Rahasia Sukses Membangkitkan ESQ Power: Sebuah Inner Journey Melalui Ihsa. Jakarta: ARGA.

Azzel, Akhmad Muhaimin. 2011. Urgensi Pendidikan Karakter di Indonesia; Revitalisasi Pendidikan Karakter terhadap Keberhasilan Belajar dan Kemajuan Bangsa. Yogyakarta: Ar Ruzz Media.

Baharuddin. 2010. Psikologi Pendidikan Refleksi Teoritis terhadap Fenomena. Yogyakarta: Ar-Ruzz Media.

Bambang Q Anees dan Adang Hambali. 2008. Pendidikan Karakter Berbasis Al-Quran. Bandung: Simbiossa Rekatama Media.

Cholid Narkubo. 2003. Metodologi Penelitian. Jakarta: Bumi Aksara.

Depdiknas. 2004. Kurikulum 2004 Standar Kompetensi Pendidikan Agama Islam SMA dan MA. Jakarta: Pusat Kurikulum Balitbang Depdiknas.

Elias, J. L. 1989. Moral Education: Secular And Religious. Florida: Robert E. Krieger Publishing Co., Inc.

Endin Mujahidin. 2005. Pesantren Kilat Alterantif dan Metode Penelitian Sosial. Yogayakarta: Pustaka Pelajar.

Gea Atoshoki, Antonius dan Wulandari, Antonina Panca Yuni. 2005. Character Building IV: Relasi dengan Dunia. Jakarta: PT. Gramedia.

| Volume. 1, No. 1, Januari-Juni 2016 
Hafidhudin, Didin dan Tanjung Henri. 2003. Manajemen Syariah dalam Praktik. Jakarta: Gema Insani.

Hari Cahyono, Cheppy. 1987. Ilmu Budaya Dasar. Surabaya: Usaha Nasional.

Kesuma Dharma, dkk. 2011. Pendidikan Karakter Kajian Teori dan Praktik di Sekolah. Bandung: PT. Remaja Rosda Karya.

Malik Fadjar. 2005. Holistika Pemikiran Pendidikan. Bandung: Raja Grafindo Persada.

Moleong, Lexy J. 2011. Metodologi Penelitian Kualitatif Edisi Revisi. Bandung: Remaja Rosda Karya.

Muchlas Samani dan Hariyanto. 2011. Konsep dan Model Pendidikan Karakter. Bandung: Remaha Rosdakarya.

Muhaimin. 2009. Pengembangan Kurikulum dan Pembelajaran: Upaya Reaktualisasi Pendidikan Islam. Malang: LKP2I.

Muhaimin. 2009. Rekonstruksi Pendidikan Islam dari Paradigma Pengembangan, Manajemen Kelembagaan, Kurikulum hingga Strategi Pembelajaran. Jakarta: Raja Grafindo Persada.

Munzali F. 2010. Konsep Budaya dan Iklim sekolah, Pendidikan Karakter: Membangun Delapan Karakter Emas Menuju Indonesia Bermartabat. Yogyakarta : Samudra Biru.

Nasution. 2007. Method Research: Penelitian Ilmiah. Jakarta: PT. Bumi Aksara.

Nawawi, Hadari. 2001. Manajemen Sumber Daya Manusia. Yogyakarta: Gajahmada University Press.

Oteng Sutisna. 1989. Administrasi Pendidikan. Bandung: Angkasa.

Pitakasari, Ajeng Ritzki. 2011. Rendah, Indeks Manusia Indonesia Hanya di Peringkat 124 Dunia. http://republika.co.id/berita/nasional/umum/ 11/11/27/lva76orendah- indeks- manusia- indonesia- hanya- di- peringkat-124-dunia, diakses tanggal 22 Januari 2016

Ratna Megawangi. 2007. Semua Berakar pada Karakter. Jakarta: Lembaga Penerbit FE UI.

Rohmat. 2012. Pilar Peningkatan Mutu Pendidikan. Yogyakarta: Cipta Media Aksara.

Safefe'i Rachmat. 2000. Al Hadits Akidah Akhlak Sosial dan Hukum. Bandung: CV. Pustaka Setia

Sarumpaet.,R.I. 2001. Rahasia Mendidik Anak. Bandung: Indonesia Publishing House. 
Suarto Ahmad dan Noor Muhammad. 2008. Himpunan Hadits Shahih Bukhari. Jakarta: Annur Press

Tim Dosen Administrasi Pendidikan UPI. 2009. Manajemen Pendidikan. Bandung: Alfabeta.

Ummatin Khoiro. 2011. 40 Hadits Shahih MEngintip Nabi Mendidik Buah Hati. Yogyakarta: Pustaka Pesantren

Undang-Undang SISDIKNAS (Sistem Pendidikan Nasional) No. 20 Tahun 2003 Pasal 3. Jakarta: Sinar Grafika.

Wahjosumidjo. 2002. Kepemimpinan Kepala Sekolah Tinjauan Teoritis dan Permasalahannya. Jakarta: PT. Raja Grafindo Persada.

Widjajakusuma M.K dan Yuswanto M.I. 2003. Pengantar Manajemen Syariat, Jakarta: Khairul Bayaan.

William, T. Russel dan Megawangi Ratna. 2011. Dampak Pendidikan Karakter Terhadap Akademi Anak, http://pondokibu.com/dampak-pendidikan-karakterterhadap-akademi-anak.html, diakses Tanggal 23 Januari 2016.

Yuswanto, M I dan Widjayakusuma MK. 2003. Manajemen Strategis Perspektif Syariah, Jakarta : Khairul Bayaan.

Zins, Joseph. 2001. Emotional Intelligence dan School Success. New York: Penguin. 
90 Nur Hidayah

Pengembangan Kultur Sekolah Berbasis Syariah Dalam Pembentukan Karakter Siswa Di SMK IT Smart Informatika Surakarta 